\title{
The impact of trading-restricted, business days and trading, non-business days on Australian small-cap, large- cap and market returns ${ }^{\dagger}$
}

\author{
Mitesh Mistry $^{\mathrm{a}}$, Andrew Worthington ${ }^{\mathrm{b}, \ddagger}$, Dionigi Gerace ${ }^{\mathrm{c}}$, Chandra Gulati ${ }^{\mathrm{a}}$ \\ ${ }^{a}$ School of Mathematics and Applied Statistics, University of Wollongong, Wollongong, NSW 2522, Australia. \\ ${ }^{b}$ Department of Accounting Finance and Economics, Griffith University, Nathan, QLD 4111, Australia. \\ ${ }^{c}$ School of Accounting and Finance, University of Wollongong, Wollongong, NSW 2522, Australia.
}

\begin{abstract}
This paper comprises an empirical analysis of trading-restricted, business days and trading, non-business days on the Australian Securities Exchange (ASX). Trading-restricted, business days refer to days where trading hours are shorter but business activity (including settlement) is normal; trading, non-business days refer to days where trading takes place almost normally but the settlement of securities is delayed. Seven days are included in the analysis: the Bank Holiday in NSW (non-business), Labour Day in NSW (non-business), Easter Thursday (early close), Labour Day in Victoria (non-business), Melbourne Cup Day in Melbourne (non-business), the last business day before Christmas (early close) and the last business day of the calendar year (early close). Three indexes provide different daily return measures: the All Ordinaries (market), 1958-2007, the Small Ordinaries (small-cap), 19942007; and the ASX100 (large-cap), 1992-2007. The trading-restricted, business day and trading, non-business day effect is examined using non-parametric and regression methods. The findings indicate return abnormalities on three days when trading and/or business activity is restricted: Melbourne Cup Day, the last business day before Christmas and the last business day of the year.
\end{abstract}

JEL classification: C12; C22; G14

Keywords: security trading, settlement and clearing; market efficiency; holiday effect

\section{Introduction}

The theory of market efficiency proposes that securities prices fully reflect all available information to all market participants. It also assures that the market price mechanism acts accurately and instantaneously to the disclosure of any information. However, many empirical studies have suggested deviations from market efficiency with the presence of unexpected or anomalous regularities in the rates of return on individual securities and indices. A number of empirical studies have duly documented anomalies associated with days of the week, days of the

\footnotetext{
${ }^{\dagger}$ Paper presented to the Asian Finance Association 2009 International Conference, Brisbane, 30 June-3 July, 2009.

₹ Presenting author: Department of Accounting, Finance and Economics, Griffith University, Nathan QLD 4111, Australia. Tel. +61 (0)7 3735 4273; Fax. +61 (0)7 3735 3719; Email. a.worthington@griffith.edu.au.
} 
month, months of the year, and cultural and festive holidays. Together these findings challenge the theory of market efficiency, particularly weak-form efficiency, which suggests that superior returns are not attainable through the analysis of historical data.

One aspect of seasonality that has received rather less attention concerns other systematic patterns in the trading, settlement and clearing of securities on organised exchanges. Consider the Australian Securities Exchange (ASX). As shown in Table 1, a typical trading day on the ASX is a day other than a Saturday, Sunday, New Year's Day, Good Friday, Easter Monday, Christmas Day, Boxing Day, and any other day which the Exchange declares and publishes is not a trading day. On these days, trading takes place 10:00-16:00 Australian Eastern Standard Time (AEST) via the Stock Exchange Automated Trading System (SEATS). A business day is a day other than a Saturday, Sunday, New Year's Day, Good Friday, Easter Monday, Christmas Day, Boxing Day, and any other day which the Exchange shall declare and publish is not a business day. On these days, the ASX Settlement and Transfer Corporation (ASTC) through the Clearing House Electronic Subregister System (CHESS) and the Australian Clearing House (ACH) via the Derivatives Clearing System (DCS) coordinate settlement activities for equities and derivatives, respectively. Outside these days, trading closes and settlement does not place: this applies, of course, to Saturdays and Sundays, along with national public holidays like New Years Day, Australia Day, Good Friday and Easter Monday, Christmas Day and Boxing Day.

\section{$<$ TABLE 1 HERE $>$}

However, two additional categories of days exist on the ASX that encompass restrictions in trading or settlement alone. The first category is where trading is restricted through an early close (10:00-14:15): this arises on trading days before selected public holidays and includes Easter Thursday, the last business day before Christmas and the last business day of the year. Settlement and all other business activities are undertaken normally. In this study, these are denoted as 'trading-restricted, business days' as against 'trading, business days'. The second category relates to days where trading proceeds as normal, but the clearing and settlement of securities is postponed until the next business day. Typically, this arises with public holidays in either New South Wales (Sydney) or Victoria (Melbourne) when trading closes. The presence of trading nonbusiness days results in a market where active trading occurs, though partially restricted by the 
absence of at least some market participants in these major financial centres, and business activities do not take place. These are referred to as 'trading, non-business days'.

The impact of a non-business day is as follows. The current arrangement for the settlement and clearing of transactions on the ASX are completed in three trading days of being executed on a fixed basis. This settlement process is referred to as the $\mathrm{T}+3$ system. This means that if a trade is executed on a Monday, it will be settled on the upcoming Thursday and similarly if a trade is performed on a Wednesday it will be settled on the following Monday. A seller will need to deliver the sold securities on the third business day after the trade date and will receive their funds on the third business day. The buyer will likewise have an obligation to pay for the securities on the third business day after the trade date. However, if within the settlement period a non-business day occurs, the settlements of those securities are postponed by a day, resulting in four-day (three-business day plus one non-business day) settlement. Benefits from this fixed system, amongst other things, strengthened market efficiency according to ASX Managing Director Richard Humphry at the time of its adoption in 1999, “The change is part of a global program to minimise counterparty risk and market exposure associated with longer settlement periods. While these risks are less significant in Australia because of the protection offered by ASX's National Guarantee Fund, it is still important for the Australian market to maintain international parity”.

The purpose of this paper is to consider the impact of trading-restricted, business days and trading, non-business days on Australian market returns. Although some research in this area exists in the United States and elsewhere, Australian studies concerning the impact of these departures from usual transaction and settlement behavior are relatively unknown. Further while trading-restricted, business days approximate pre-holiday trading days in some respects (though with shorter trading days), trading, non-business days represent a novel disjunction between conventional trading and settlement activity. The remainder of the paper is structured as follows. Section 2 provides a brief literature review. Section 3 explains the data methodology employed in the analysis. The results are dealt with in Section 4. The paper ends with some concluding remarks in the final section.

\section{Literature review}


Three aspects of the literature are relevant to this analysis. These are: (i) the settlement and clearing hypothesis, normally used to explain the day-of-the-week effect; (ii) the holiday effect, typically linked with higher pre-holiday daily returns; and (iii) the individual vs. institutional hypothesis, usually associate with purported differences in the trading behaviour of individuals and institutions and the possible impact on the pattern of daily returns.

\subsection{Settlement and clearing hypothesis}

The settlement and clearing hypothesis argues that the day-of-the-week effect can be linked with the differences in time between the purchase of a security and its settlement (Crouchy and Galai 1992). In one of the earlier studies, Gibbon and Hess (1981) considered the impact on the DowJones Industrial Average (DJIA) when the New York Stock Exchange (NYSE) settlement period changed in 1968 from four to five days. While negative returns persisted on the next trading day, Gibbon and Hess (1981) concluded that a small proportion of seasonality (in the form of the weekend effect) is attributable to the settlement regime. More recently, a study of the Kuala Lumpur Stock Exchange by Clare et al. (1998) also found that the settlement and clearing of securities contributed to the weekend effect. Prior to the introduction of a new fixed settlement system, uncertainty had existed around settlement payments as sellers had up until the following Wednesday to deliver their shares. However, after the introduction of the new fixed delivery and settlement system, Clare et al. (1998) concluded that the seasonality effect found in the past had almost vanished.

In terms of cross-institutional analyses, Jaffe and Westerfield (1985) concluded that settlement procedures in the UK, Canada and Japan markets did not cause any seasonality effects, but some aspects of settlement procedure had a role to play in the Australian market. However, while Australian settlement procedures could be linked with abnormally high returns on Friday trading day, this was not possible with the largely negative returns on the following Monday. Conversely, Agrawal and Tandon (1994) suggested that no feasible relationship existed between seasonality effects and the settlement and clearing of securities as many financial markets had differing settlement days “...ranging from one day in France and Hong Kong, to six to fifteen days in the U.K. Thus, it is hard for differences in the settlement periods to explain the consistent negative pattern on Monday or Tuesday that we find in most countries” (Agrawal and Tandon 1994: 92). 
For example, Agrawal and Tandon (1994) provided an illustration of the potential behaviour of financial markets in the Netherlands, Japan and Sweden, all of which had a settlement period of four days. This meant that if an investor bought a security on Monday and sold the same security on Tuesday, the investor would pay for the security on Friday and receive payment for the security on the following Monday. Agrawal and Tandon (1994) suggested that since the cash payment occurs three days prior to the cash receipt, these markets should realise higher return on the Tuesday trading day to compensate for the loss of interest over the weekend. However, strong negative returns were found instead. These and other results suggest that the settlement and clearing hypothesis provides a feasible explanation for some daily return patterns in some financial markets but not in others.

\subsection{Holiday effects}

The holiday effect is where higher expected returns are thought to occur on trading days prior to a holiday. Given the volume of work in this area, it is instructive to first consider three early studies by Lakonishok and Smidt (1988), Ariel (1990) and Cadsby and Ratner (1992). To start with, Laskonishok and Smidt (1988) employed approximately ninety years of daily returns data from the DJIA to divide trading days into three distinct categories—pre-holiday, post-holiday and ordinary trading days. They concluded that the average returns of nine hundred and fifteen preholiday days was 0.22 percent, compared to a return of only -0.0017 percent on post-holidays and 0.0094 percent on all other trading days. This indicated that pre-holiday returns were more than twenty-three times larger than the ordinary trading day rate of return. Further, while preholidays only accounted for 4.2 percent of all trading days, they could be linked with approximately 50 percent of the total advances in the DJIA over the ninety-year period. Analysis of different sub-periods showed that these results appeared to be consistent, with the exception of the most-recent period (1976-1986) where the pre-holidays returns was positive but insignificant. According to Ariel (1990), pre-holidays displayed abnormal returns nine to fourteen times higher than other days of the week. Using Center for Research in Security Prices (CRSP) equal- and value-weighted indexes, these abnormal returns were found to be independent of the dataset employed and that they did not derive from a small number of very high returns from the period of 1963 to 1982. Ariel (1990) also provided some evidence that the pre-holiday effect was not a manifestation of other calendar anomalies, such as the January or weekend effect, that the pre- 
holiday volatility in returns are distinctly lower than that for non-holiday returns, and that the holiday effect occurs only on a single trading day prior to the actual holiday. Further, using intraday data, Ariel (1990) concluded that the holiday effect is effectively the result of the last hour of trading.

Finally, Cadsby and Ratner (1992) examined global markets for evidence of the holiday effect. The aim of their study was to investigate firstly whether nine non-US markets exhibited the same pre-holiday effects seen in the US market, and secondly to test for the impact of the US holiday effect on other markets (i.e. a test for independence). The results indicated that eight countries, which shared the same holiday as a US holiday illustrated higher returns than non-holiday trading returns. Moreover, there appeared to be evidence of independencies in some markets, indicating that market integration may partially explain effects unexplained by local holidays. The main findings were that all non-European countries in the study exhibited significant local pre-holiday effects; that no European country showed evidence of a pre-holiday effect; and that Hong Kong was the only market that reflected US holiday effects. On this basis, Cadsby and Ratner (1992) noted that pre-holiday effects could depend solely on local market participation and vary with differences in neighbouring institutions and practices.

More recent work has added additional insights into the holiday effect. In their analysis of the Japanese, UK and US markets, Kim and Park (1994) initially found that it was obvious that there were significantly higher mean returns on trading days before holidays. However, post-holiday effects were found to not exhibit any irregular pattern, leading to the conclusion that holiday effects simply comprise the irregular returns seen on the last pre-holiday trading day. Kim and Park (1994) also found that smaller firms displayed higher mean pre-holiday returns than larger firms. Most importantly, Kim and Park (1994: 156) concluded:

The persistent of the holiday effect across countries suggest that the holiday effect is not driven by institutional arrangement unique to the stock market of a country. Therefore, institutional factors such as trading methods, clearing mechanism, settlement procedure and bid-ask spreads cannot be possible explanations for international evidence of the holiday effect because these institutional factors are different across countries.

Using a similar approach, Vergin and McGinnis (1999) found diminishing excess returns in both large and small-sized firms around holidays. Eight US holidays was examined using four different indexes (S\&P 500, NYSE Composite Index, NASDAQ and American Stock Exchange Composite Indices) as proxies for differences in firm size. Prior to 1987, strong evidence was 
found of irregular market behaviour around public holidays. However, after 1987 the holiday effect effectively disappeared in large firms, and faded in small firms. Most recently, Keef and Roush (2005) examined pre-holiday returns in the S\&P Index from 1930 to 1999. The three main findings include the diminishment of the pre-holiday effect after 1987; no evidence of a weekend effect in pre-holiday returns; and finally that Labor Day returns were significantly greater than returns before other holidays falling on a Monday.

\subsection{Individual vs. institutional hypothesis}

At least some studies have argued that the day-of-the-week effect and other forms of seasonality almost exclusively relate to the differing trading behaviour of individual and institutional investors. Much speculation exists as to which particular group is responsible: Lakonishok and Maberly (1990) and Abraham and Ikenberry (1994), for example, directly relate seasonality to the trading behaviour of individual investors while Sias and Starks (1995) suggest that institutional investors' trading patterns are the primary cause.

Arguments supporting individual investors trading behaviour as the cause of seasonality could be the result of timely recommendations from stockbrokers (Miller 1988), or the 'inherent psychology' of investors - such as their personal moods, perceptions and emotion (Rystrom and Benson 1989). Other work includes Abraham and Ikenberry's (1994) suggestion that individual investors use Monday trading days to satisfy their liquidity needs flowing from the negative returns seen on the previous Friday and Lakonishok and Maberly's (1990) hypothesis that it is less costly for individuals to gather and process information on weekends than weekdays. Conversely, Sias and Starks (1995) propose that day-of-the-week patterns in volumes and returns are largely the result of institutional investors since securities with larger institutional investor holdings exhibit greater seasonality than comparably sized securities held by individual investors. More recently, academics have also linked the holiday effect to the behaviour and actions of individual investors. Meneu and Pardo (2004) argue that the holiday effect is attributed to increases in the average size bid orders placed by investors prior to holidays. Brockman and Michayluk (1998) and Jacobs and Levy (2000), on the other hand, have suggested that investor's psychology may play a role in the high pre-holiday returns. They argue that investors may look favourably towards the upcoming holiday and react by applying buying pressure, resulting in higher pre-holiday returns. 
Brooks and Kim (1997), however, argue that both institutions and individuals are responsible for some seasonal effects as individual investors play a role through their trading patterns and institutional investors via their absence in trading. Using intraday data, Brooks and Kim (1997) found more small-sized transactions linked to individual investors and fewer large-sized orders representing institutional investors' transactions. The absence of institutional investors reduces liquidity in the market and provides evidence that both parties are accountable for the present of seasonality effects.

\section{Empirical methodology}

This study examines the impact of three trading-restricted, business days (Easter Thursday, the last business day before Christmas and the last business day of the year) and four trading, nonbusiness days (Labour Day in Victoria, the Bank Holiday in NSW, Labour Day in NSW and Melbourne Cup Day in Victoria) on ASX returns. Additional details are included in Table 1. As discussed, the trading-restricted, business days have the appearance of pre-holiday trading days with the exception that the trading day is 105 minutes shorter. Importantly, the trading, nonbusiness days theoretically associated with normal trading days also involve some restrictions in trading. For instance, Melbourne Cup Day is a public holiday in Melbourne (Australia's secondlargest capital city), Labour Day is a holiday in Victoria (Australia's second-largest state), and Labour Day and the Bank Holiday in NSW is a public holiday in NSW (Australia's largest state, with Sydney as Australia's financial capital). Moreover, Victoria shares Labour Day with Tasmania's Eight Hours Day and South Australia's Adelaide Cup Day, while Labour Day in NSW is common with South Australia and the Australian Capital Territory along with the Queens's Birthday in Western Australia. The inference is that trading, non-business days also involve the potential removal of large numbers of market participants.

Returns are measured using three value-weighted indices; the All Ordinaries measures market returns (representing some 92\% of total market capitalisation), the Small Ordinaries the returns on small-cap stocks (approximately 8\% of market capitalisation), and the ASX100 the returns on large-cap stocks (the one hundred largest firms by capitalisation). The long-term daily data for the first series is from Global Financial Data (2007) while the data for small and large-cap firms is from DataStream (2007). The analysis draws upon the maximum sample length for each index: 6 January 1958-13 August 2007 for the market ( $n=12,477), 4$ January 1994-31 August 2007 for 
small-caps ( $n=3$,463), and 1 June 1992-31 August 2007 for the large-caps $(n=3,869)$. Following Vergin and McGinnis (1999), Keef and Roush (2005) and Worthington (2007), the market return index is divided into two sub-samples using a Chow breakpoint test: pre-1987 from 6 January 1958 to 19 October 1987 and post-1987 20 October 1987 to 13 of August 2007.

The daily returns for each specified index employ the logarithmic or continuously compounded formula:

$$
R_{t}=\ln \left(\frac{P_{t}}{P_{t-1}}\right) \times 100
$$

where $R_{\mathrm{t}}$ is the daily return, $P_{t}$ is the closing value of the index on day $t$ and $P_{t-1}$ is the closing value of the index on the previous day.

Two approaches are used to test for the trading-restricted, business day and trading, non-business day effects. The first employs nonparametric tests of differences in mean returns and the variance of returns. The second is a regression-based approach where:

$$
\begin{aligned}
R_{i t} & =\beta_{0}+\beta_{i 1} \text { Labour Day (VIC) }+\beta_{i 2} \text { Easter Thursday }+\beta_{i 3} \text { Bank Holiday } \\
& +\beta_{i 4} \text { Labour Day (NSW) }+\beta_{i 5} \text { Melbourne Cup Day } \\
& +\beta_{i 6} \text { Last Day before Christmas Day }+\beta_{i 7} \text { Last Day before End of Year }+\varepsilon_{i t}
\end{aligned}
$$

where $\mathrm{R}_{\mathrm{it}}$ is the daily return on index $i$ on day $t$, Labour Day (VIC), Easter Thursday, Bank Holiday, Labour Day (NSW), Melbourne Cup Day, Last Day before Christmas Day and Last Day before End of Year are binary dummy variables that equal one for the day specified, otherwise zero, and $\varepsilon$ is the error term.

\section{Empirical results}

The number of observations, means, standard deviations, maximums and minimums of daily market, small-cap and large-cap returns for the trading-restricted business days, trading, nonbusiness days and trading, business days are detailed in Table 2. Also included are distributional statistics for skewness and kurtosis. As shown, there is already some indication that the dispersion and distribution of returns vary across the various categories. For example, the mean market return on a trading business day is 0.028 percent with returns (in brackets) being higher on Easter Thursday (0.088), Labour Day (NSW) (0.058), Melbourne Cup Day (0.179), and the 
last days before Christmas (0.360) and the end of the year (0.298), and lower on Labour Day (VIC) (-0.047) and the Bank Holiday (0.016). The standard deviations also differ, with higher standard deviations (in brackets) on the Bank Holiday (1.122) and lower standard deviations on Labour Day (VIC) (0.853), Easter Thursday (0.504), Labour Day (NSW) (0.774), Melbourne Cup Day (0.551) and the last days before Christmas (0.392) and the end of the year (0.585) relative to trading business days (0.845). In terms of distribution, daily returns on Labour Day (VIC), Easter Thursday, Labour Day (NSW) and all other days exhibit significant negative skewness or the increasing likelihood of negative values (the remaining days are all positively skewed), while all series show evidence of leptokurtic or fat-tailed distributions with relatively many extreme observations.

\section{$<$ TABLE 2 HERE $>$}

Nonparametric tests for equality of the variances and means are provided in Tables 3 and 4 , respectively. The null hypotheses are that the daily variances and means for the respective trading-restricted business days and trading, non-business days are equal to all other (trading business) days. The tests for equality of variance are used to inform whether the tests for equality of means assume equal or unequal variances. To start with, there are significant different variances signifying the volatility of returns for market returns on Easter Thursday, the Bank Holiday, Melbourne Cup day and the last day before Christmas. The pre-1987 market returns show that these differences are relatively consistent for the first sample period, though joined by the last day of the year. However, in the post-1987 sample period only the variance for the last day before Christmas is significantly different from all other days. For small and large cap returns, the variances on the last day before Christmas are again less, but none of the other trading-restricted business days or trading non-business days exhibits any significant differences in variance.

\section{<TABLE 3 HERE >}

In terms of the daily market returns, the mean return is significantly higher on the last day before Christmas (0.360) and the last day of the year (0.298) when compared with trading, business days (0.028). This also holds for the pre-1987 sample along with lower mean returns on Labour Day (VIC) and higher means returns on Easter Thursday. In the post-1987 sample period, there are 
higher mean returns on Labour Day (VIC), Melbourne Cup Day and the last days before Christmas and the end of the year. These are generally consistent with the post-1987 sample period except that the difference in mean returns for Easter Thursday are no longer significant, and Melbourne Cup Day is now significantly higher along with Labour Day (VIC). For smallcap returns, the means are higher on the last day of the year, while for large-cap returns they are higher on Labour Day (VIC), Melbourne Cup Day and the last day before Christmas. One this basis, the firm size effect in trading, business days returns appears inconclusive, in that larger and smaller capitalised stocks appear to show different patterns of significant return differences to the market as a whole and each other in some respects. One basic observation is that the last day before Christmas effect would appear to derive from large-caps, while the last day of the year effect seems to develop from small-caps.

\section{<TABLE 4 HERE>}

The estimated coefficients and standard errors for the regression equation in (2) are presented in Table 5. The table also includes values for $R^{2}$ and adjusted $R^{2}$ and the $F$-statistics and $p$-values of the null hypotheses that all slope coefficients are zero. Breusch-Godfrey Lagrange multiplier and White's heteroskedasticity tests (not shown) are used initially to test for higher-order serial correlation and heteroskedasticity in the least squares residuals, respectively. To start with, the null hypothesis of no serial correlation is rejected and we may conclude the presence of higherorder serial correlation in the residuals. Then the null hypothesis of no heteroskedasticity in the least squares residuals fails to be rejected and we conclude the presence of heteroskedasticity in the least squares residuals. Accordingly, the standard errors employ corrections for heteroskedasticity and autocorrelation of unknown form (Newey-West).

\section{$<$ TABLE 5 HERE $>$}

Consistent with the finding of the non-parametric analysis, there appears to be one trading nonbusiness day and two trading-restricted business days that exert a significant impact at the market level (columns 1 and 2): namely, Melbourne Cup Day, and the last business day of the year and the last business day before Christmas Day, respectively. The magnitude of these impacts appears to be substantial. For example, based on a market capitalisation of $\$ 1,532$ billion in November 2007, the trading, non-business day effects on Melbourne Cup Day adds an additional \$2,742 
million to market capitalisation (six times normal daily returns). The trading-restricted business day effect on the other hand adds $\$ 5,515$ million on the last day before Christmas (thirteen times normal returns) and $\$ 4,565$ million on the last day of the year (ten times normal returns). Separate regressions for small-caps (columns 3 and 4) and large caps (columns 5 and 6) again show that the market effect appears to be dominated by small caps for the last day before Christmas and the end of the year, while large caps play a role in the Melbourne Cup Day effect and the last day before Christmas. However, the relative impact of the trading-restricted business days and trading, non-business days appears relatively small, explaining in all instances less than one percent of the variation in returns over the various sample periods.

The regressions results also suggest that these anomalies are inconsistent over time. The pre-1987 sample shows significantly higher returns on Easter Thursday, the last business day before Christmas Day and year-end and significantly lower returns on Labour Day (VIC). However, the regression coefficients in the post-1987 sample period indicate higher returns on Melbourne Cup day and the last day before Christmas and year-end. Moreover, the share of variation accounted for by the trading-restricted, business day and trading, non-business day effects has declined. In fact, the null hypothesis of the joint insignificance of the slope coefficients fails to be rejected for the later sample period.

\section{Concluding Remarks}

The study investigates posited return anomalies associated with trading-restricted, business days and trading, non-business days on the Australian Stock Exchange. On the former, trading hours are restricted due to the proximity of the public holidays on Easter Thursday and Christmas and on the last business day of the year. On the later, trading proceeds normally, though with the removal of some market participants because of public holidays in some states, while settlement activity is postponed. Potentially, these departures from normal trading, business activity thereby comprise a combination of the pre-holiday effect known in the literature and the various settlement hypotheses. The result show strong evidence of return anomalies associated with Melbourne Cup Day, the last business day of the year and the last business day before Christmas day, and these appear to be consistent across the market, small-cap and large-cap stocks. For this reason, the analysis provides inconclusive evidence of a firm size effect, suggesting that restrictions in trading and/or settlement act almost equally upon firms. 
The most puzzling aspect of this analysis is that it has been possible to identify the underlying cause of the return anomalies. In many cases, there are a number of competing hypothesises that potentially provide an explanation. Consider Melbourne Cup Day. As a non-business day, market activity may intensity and returns increase with the benefits of a delay in settlement. The results of this analysis provide some indirect support here. However, this could also be result of the market euphoria associated with Australia's premier horse race, as argued by Worthington (2007) with a behavioural finance approach. In either instance, this must be strong enough to offset the reduction in market participation with the public holiday in Victoria. Now consider the last trading days before Christmas and the end of the year. Once again, the evidence found of relatively higher returns on these days, while consistent with a pre-holiday effect lies at odds with a trading day that is nearly thirty percent shorter.

There are a number of possible future directions for research stemming from these and other limitations. One of the more important of these is the extension of the data used to include not only returns but also trading volumes, bid-ask spreads and other market information. For example, trading, non-business days are not only associated with a delay in settlement but also the potential removal of large numbers of market participants and the limited release of price and non-price sensitive company information in some states. As these days are associated with higher returns than normal trading, business days it is not known whether this result truly represents an inconsistency with the lower hypothesised level of market activity or whether broad market activity is entirely unaffected by regional holidays. Another extension would involve intra-day data. This would allow a more robust analysis of trading-restricted business days in that interest could be focused on the pattern of trades throughout the day and the role of the last few hours of trading on daily returns.

\section{References}

Abraham, A. and D. L. Ikenberry (1994). "The individual investor and the weekend effect.” The Journal of Financial and Quantitative Analysis 29(2):263 - 277.

Agrawal, A. and K. Tandon (1994). "Anomalies or illusions? Evidence from stock markets in eighteen countries." Journal of International Money and Finance 13(1): 83 - 106.

Apolinario R.M., O.M. Santana, L.J. Sales and A.R. Caro (2006). "Day of the Week Effect on European Stock Markets” International Research Journal of Finance and Economics, 2:53 - 70.

Brockman, P. and D. Michayluk (1998). "The persistent holiday effect: additional evidence." Applied Economics Letters 5(2): 205 - 209.

Brooks, M. B. and H. Kim (1997). "The Individual Investor and the Weekend effect: A Reexamination with Intra Day data.” The Quarterly Review of Economics and Finance 37(3): 725 - 737. 
Cadsby, C. B. and M. Ratner (1992). "Turn-of-the-month and pre-holiday effects on stock returns: Some International evidence." Journal of Banking and Finance 16(3): 497 - 509.

Chan, M. W. L., A. Khanthavit, et al. (1996). "Seasonality and Cultural Influences on Four Asian Stock Markets." Asia Pacific Journal of Management 13(2): 1 - 24.

Clare, A.D., M.S.B. Ibrahim and S.H. Thomas (1998). "The impact of settlement procedures on day-of-the-week effects: evidence from the Kuala Lumpur stock exchange.” Journal of Finance and Accounting 25(3 and 4):401 - 418.

Crouhy, M. and D. Galai (1992). "The Settlement Day Effect in the French Bourse.” Journal of Financial Services Research 6(4):417 - 435.

DataStream (2007) Available at http://www.datastream.com/.

Easton, S. A. and R. W. Faff (1994). "An investigation of the robustness of the day-of-the-week effect in Australia." Applied Financial Economics 4(1): 99 - 110.

Gao, L. and G. Kling (2005). “Calendar Effects in the Chinese Stock Market.” Annals of Economics and Finance 6: $75-88$.

Gibbons, M. and P. Hess (1981). "Day of the Week Effects and Asset Returns." Journal of Business 54(4): 579 596.

Global Financial Data (2007) Available at http://www.globalfindata.com/

Jaffe, J. and R. Westerfield (1985). “The week-end effect in common stock returns: The international evidence.” The Journal of Finance 40(2):433 - 454.

Keef, S. P. and M. L. Roush (2005). "Day-of-the-week effects in the pre-holiday returns of the Standard \& Poor's 500 stock index." Applied Financial Economics 15(1): 107 - 119.

Kim, C.W. and J. Park (1994). "Holiday Effects and Stock Returns: Further Evidence." Journal of Financial and Quantitative Analysis 29(1): 145 - 157.

Lakonishok, J. and E. Maberly (1990). "The Weekend effect: Trading patterns of individual and institutional investors." The Journal of Finance 45(1): 231 - 243.

Lakonishok, J. and S. Smidt (1988). "Are Seasonal Anomalies Real? A Ninety-Year Perspective." The Review of Financial Studies 1(4): 403 - 425.

Liano, K., P.H. Marchand and G.C. Huang (1992). "The holiday effect in stock returns: evidence from the OTC market.” Review of Financial Economics 2(1): 45 - 54.

Marquering, W., J. Nisser, et al. (2006). "Disappearing anomalies: a dynamic analysis of the persistence of anomalies." Applied Financial Economics 16(4): 291 - 302.

Marrett, G. and A.C. Worthington (2007). "An empirical note on the holiday effect in the Australian stock market, 1996-2006” School of Accounting and Finance Working Paper, University of Wollongong. Available at http://ro.uow.edu.au/commpapers/337/.

Meneu, V. and A. Pardo (2004). "Pre-holiday effect, large trades and small investor behaviour." Journal of Empirical Finance, 11(2): 231 - 246.

Miller, E. (1988). "Why a Weekend Effect." Journal of Portfolio Management 14(4): 43 - 48.

Officer, R. R. (1975). "Seasonality in Australian capital markets." Journal of Financial Economics 2(1): 29 - 51.

Pettengill, G. N. (1989). "Holiday closings and security returns.” Journal of Financial Research, 12(1): 57 - 67.

Rystrom, D. S. and E. D. Benson (1989). "Investor Psychology and the Day-of-the-week." Financial Analysts Journal 45(5): 75 - 78.

Sias, R. W. and L.T. Starks (1995). “The day-of-the-week anomaly: The role of institutional investors.” Financial Analyst Journal 51(3): 58 - 67.

Vergin, R. C. and J. McGinnis (1999). "Revisiting the Holiday Effect: is it on holiday?" Applied Financial Economics 9(3): 477 - 482.

Worthington, A.C (2007). "National exuberance: A note on the Melbourne Cup effect in Australian stock returns." Economic Papers 26(2): 170-179

Ziemba, T. W. (1989). "Japanese security market regularities: monthly, turn of the month and year, holiday and golden week effects.” Japan and the World Economy 3(2): 119 - 146. 
Table 1. 2007 Australian Stock Exchange (ASX) financial calendar

\begin{tabular}{|c|c|c|c|c|c|c|c|}
\hline Public Holiday & Date & $\begin{array}{l}\text { Day and date } \\
\text { in } 2007\end{array}$ & $\begin{array}{l}\text { Applies to the } \\
\text { following States }\end{array}$ & $\begin{array}{l}\text { Trading } \\
\text { Day }\end{array}$ & $\begin{array}{l}\text { Settlement } \\
\text { Activity - } \\
\text { ASTC } \\
\text { (CHESS) } \\
\end{array}$ & $\begin{array}{l}\text { Settlement } \\
\text { Activity - } \\
\text { ACH } \\
\text { (DCS) } \\
\end{array}$ & $\begin{array}{c}\text { Business } \\
\text { Day }\end{array}$ \\
\hline New Year's Day & 1 January & $\begin{array}{l}\text { Monday } 1 \\
\text { January }\end{array}$ & ALL & Closed & $\begin{array}{c}\text { No } \\
\text { Settlement }\end{array}$ & $\begin{array}{c}\text { No } \\
\text { Settlement }\end{array}$ & No \\
\hline Australia Day & 26 January & $\begin{array}{l}\text { Friday } 26 \\
\text { January }\end{array}$ & ALL & Closed & $\begin{array}{c}\text { No } \\
\text { Settlement }\end{array}$ & $\begin{array}{c}\text { No } \\
\text { Settlement }\end{array}$ & No \\
\hline Labour Day & $\begin{array}{l}1^{\text {st }} \text { Monday in } \\
\text { March }\end{array}$ & $\begin{array}{l}\text { Monday } 5 \\
\text { March }\end{array}$ & WA & Open & Settlement & Settlement & Yes \\
\hline $\begin{array}{l}\text { Labour Day/Eight } \\
\text { Hours Day/ } \\
\text { Adelaide Cup Day }\end{array}$ & $\begin{array}{l}2^{\text {nd }} \text { Monday in } \\
\text { March }\end{array}$ & $\begin{array}{l}\text { Monday } 12 \\
\text { March }\end{array}$ & VIC/TAS/SA & Open & $\begin{array}{c}\text { No } \\
\text { Settlement }\end{array}$ & Settlement & No \\
\hline Easter Thursday & $\begin{array}{l}\text { Thursday before } \\
\text { Easter Sunday }\end{array}$ & $\begin{array}{l}\text { Thursday } 5 \\
\text { April }\end{array}$ & ALL & $\begin{array}{l}\text { Close } \\
\text { early }\end{array}$ & Settlement & Settlement & Yes \\
\hline Good Friday & $\begin{array}{l}\text { Friday before } \\
\text { Easter Sunday }\end{array}$ & Friday 6 April & ALL & Closed & $\begin{array}{c}\text { No } \\
\text { Settlement }\end{array}$ & $\begin{array}{c}\text { No } \\
\text { Settlement }\end{array}$ & No \\
\hline Easter Monday & $\begin{array}{l}\text { Monday after } \\
\text { Easter Sunday }\end{array}$ & $\begin{array}{l}\text { Monday } 9 \\
\text { April }\end{array}$ & ALL & Closed & $\begin{array}{c}\text { No } \\
\text { Settlement }\end{array}$ & $\begin{array}{c}\text { No } \\
\text { Settlement }\end{array}$ & No \\
\hline Easter Tuesday & $\begin{array}{l}\text { Tuesday after } \\
\text { Easter Sunday }\end{array}$ & $\begin{array}{l}\text { Tuesday } 10 \\
\text { April }\end{array}$ & TAS & Open & Settlement & Settlement & Yes \\
\hline $\begin{array}{l}\text { ANZAC Day } \\
\text { Holiday }\end{array}$ & 25 April & $\begin{array}{l}\text { Wednesday } \\
25 \text { April }\end{array}$ & ALL & Closed & $\begin{array}{c}\text { No } \\
\text { Settlement }\end{array}$ & $\begin{array}{c}\text { No } \\
\text { Settlement }\end{array}$ & No \\
\hline Labour Day & $\begin{array}{l}1^{\text {st }} \text { Monday in } \\
\text { May }\end{array}$ & $\begin{array}{l}\text { Monday } 7 \\
\text { May }\end{array}$ & QLD & Open & Settlement & Settlement & Yes \\
\hline Queen's Birthday & $\begin{array}{l}2^{\text {nd }} \text { Monday in } \\
\text { June }\end{array}$ & $\begin{array}{l}\text { Monday } 11 \\
\text { June }\end{array}$ & ALL except WA & Closed & $\begin{array}{c}\text { No } \\
\text { Settlement }\end{array}$ & $\begin{array}{c}\text { No } \\
\text { Settlement }\end{array}$ & No \\
\hline Bank Holiday & $\begin{array}{l}1^{\text {st }} \text { Monday in } \\
\text { August }\end{array}$ & $\begin{array}{l}\text { Monday } 6 \\
\text { August }\end{array}$ & NSW & Open & $\begin{array}{c}\text { No } \\
\text { Settlement }\end{array}$ & Settlement & No \\
\hline $\begin{array}{l}\text { Labour Day/ } \\
\text { Queen's Birthday }\end{array}$ & $\begin{array}{l}1^{\text {st }} \text { Monday in } \\
\text { October }\end{array}$ & $\begin{array}{l}\text { Monday } 1 \\
\text { October }\end{array}$ & $\begin{array}{l}\text { NSW, SA, } \\
\text { ACT/WA }\end{array}$ & Open & $\begin{array}{c}\text { No } \\
\text { Settlement }\end{array}$ & Settlement & No \\
\hline $\begin{array}{l}\text { Melbourne Cup } \\
\text { Day }\end{array}$ & $\begin{array}{l}1^{\text {st }} \text { Tuesday in } \\
\text { November }\end{array}$ & $\begin{array}{l}\text { Tuesday } 6 \\
\text { November }\end{array}$ & VIC & Open & $\begin{array}{c}\text { No } \\
\text { Settlement }\end{array}$ & Settlement & No \\
\hline $\begin{array}{l}\text { Last Business Day } \\
\text { before Christmas }\end{array}$ & $\begin{array}{l}\text { Last trading day } \\
\text { before Christmas } \\
\text { Day }\end{array}$ & $\begin{array}{l}\text { Monday, } 24 \\
\text { December }\end{array}$ & ALL & $\begin{array}{l}\text { Close } \\
\text { early }\end{array}$ & Settlement & Settlement & Yes \\
\hline Christmas Day & 25 December & $\begin{array}{l}\text { Tuesday } 25 \\
\text { December }\end{array}$ & ALL & Closed & $\begin{array}{c}\text { No } \\
\text { Settlement }\end{array}$ & $\begin{array}{c}\text { No } \\
\text { Settlement }\end{array}$ & No \\
\hline Boxing Day & 26 December & $\begin{array}{l}\text { Wednesday } \\
26 \text { December }\end{array}$ & ALL & Closed & $\begin{array}{c}\text { No } \\
\text { Settlement }\end{array}$ & $\begin{array}{c}\text { No } \\
\text { Settlement }\end{array}$ & No \\
\hline $\begin{array}{l}\text { Last Business Day } \\
\text { of the Year }\end{array}$ & $\begin{array}{l}\text { Last trading day } \\
\text { in December }\end{array}$ & $\begin{array}{l}\text { Monday } 31 \\
\text { December }\end{array}$ & ALL & $\begin{array}{l}\text { Close } \\
\text { early }\end{array}$ & Settlement & Settlement & Yes \\
\hline
\end{tabular}

Notes: ASTC - ASX Settlement and Transfer Corporation, ACH - Australian Clearing House, CHESS Clearing House Electronic Subregister System, DCS - Derivatives Clearing System, WA, Western Australia, VIC - Victoria, TAS - Tasmania, SA - South Australia, QLD - Queensland, NSW - New South Wales, ACT - Australian Capital Territory, Close early - normal trading starts at 10:00 and ends at 14:15 AEST (usually 10:00-16:00 AEST), Business Day is a day other than a Saturday, Sunday, New Year's Day, Good Friday, Easter Monday, Christmas Day, Boxing Day, and any other day which the Exchange shall declare and publish is not a business day, Trading Day is a day other than a Saturday, Sunday, New Year's Day, Good Friday, Easter Monday, Christmas Day, Boxing Day, and any other day which the Exchange declares and publishes is not a trading day. 
Table 2. Descriptive statistics of daily returns for trading, business days, trading-restricted, business days and trading, non-business days

\begin{tabular}{|c|c|c|c|c|c|c|c|c|c|}
\hline Statistic & Index & $\begin{array}{c}\text { Labour } \\
\text { Day (VIC) }\end{array}$ & $\begin{array}{l}\text { Easter } \\
\text { Thursday }\end{array}$ & $\begin{array}{c}\text { Bank } \\
\text { Holiday }\end{array}$ & $\begin{array}{l}\text { Labour } \\
\text { Day } \\
\text { (NSW) }\end{array}$ & $\begin{array}{l}\text { Melbourne } \\
\text { Cup Day }\end{array}$ & $\begin{array}{l}\text { Last day } \\
\text { before } \\
\text { Christmas }\end{array}$ & $\begin{array}{l}\text { Last day of } \\
\text { the year }\end{array}$ & $\begin{array}{c}\text { All other } \\
\text { trading } \\
\text { days }\end{array}$ \\
\hline \multirow{3}{*}{ Observations } & Market & 50 & 50 & 28 & 27 & 49 & 49 & 43 & 12180 \\
\hline & Small-cap & 14 & 13 & 14 & 13 & 13 & 13 & 13 & 3370 \\
\hline & Large-cap & 15 & 15 & 16 & 15 & 15 & 15 & 15 & 3763 \\
\hline \multirow{3}{*}{ Mean } & Market & -0.047 & 0.088 & 0.016 & 0.058 & 0.179 & 0.360 & 0.298 & 0.028 \\
\hline & Small-cap & 0.049 & -0.013 & -0.259 & 0.150 & 0.221 & 0.279 & 0.448 & 0.021 \\
\hline & Large-cap & 0.263 & -0.186 & -0.150 & 0.063 & 0.446 & 0.346 & 0.137 & 0.031 \\
\hline \multirow{3}{*}{$\begin{array}{l}\text { Standard } \\
\text { deviation }\end{array}$} & Market & 0.853 & 0.504 & 1.122 & 0.774 & 0.551 & 0.392 & 0.585 & 0.845 \\
\hline & Small-cap & 0.908 & 0.644 & 0.920 & 0.561 & 0.633 & 0.260 & 0.374 & 0.711 \\
\hline & Large-cap & 1.239 & 0.749 & 0.842 & 0.904 & 0.743 & 0.345 & 0.632 & 0.820 \\
\hline \multirow{3}{*}{ Maximum } & Market & 1.254 & 0.875 & 3.311 & 1.554 & 1.891 & 1.955 & 2.384 & 7.016 \\
\hline & Small-cap & 0.988 & 1.344 & 0.889 & 0.867 & 1.299 & 0.957 & 1.251 & 7.848 \\
\hline & Large-cap & 1.326 & 0.739 & 1.166 & 1.632 & 1.898 & 1.135 & 1.006 & 5.592 \\
\hline \multirow{3}{*}{ Minimum } & Market & -3.601 & -1.896 & -2.640 & -1.671 & -0.825 & -0.229 & -1.045 & -28.761 \\
\hline & Small-cap & -2.807 & -1.050 & -2.692 & -1.154 & -0.670 & -0.069 & -0.044 & -9.403 \\
\hline & Large-cap & -3.713 & -2.179 & -1.577 & -1.777 & -0.809 & -0.215 & -1.293 & -6.856 \\
\hline \multirow{3}{*}{ Skewness } & Market & -1.975 & -1.359 & 0.325 & -0.157 & 1.277 & 1.466 & 0.984 & -3.633 \\
\hline & Small-cap & -2.360 & 0.726 & -1.353 & -0.860 & 0.384 & 1.147 & 0.695 & -1.479 \\
\hline & Large-cap & -2.306 & -1.151 & -0.157 & -0.335 & 0.628 & 0.448 & -0.870 & -0.312 \\
\hline \multirow{3}{*}{ Kurtosis } & Market & 9.569 & 6.204 & 4.689 & 2.534 & 5.201 & 6.884 & 5.822 & 120.990 \\
\hline & Small-cap & 8.272 & 2.953 & 4.573 & 3.221 & 1.979 & 4.770 & 2.711 & 26.213 \\
\hline & Large-cap & 8.245 & 4.355 & 2.223 & 2.717 & 2.963 & 3.105 & 3.226 & 6.617 \\
\hline
\end{tabular}

Notes: Market (All Ordinaries) 6/01/1958 - 13/08/2007, Small-cap (Small Ordinaries) 4/01/1994 - 31/08/2007, Large-cap (ASX100) 1/06/1992 31/08/2007. Mean, median, maximum and minimum expressed as percentages. The critical values for skewness where $n=10,30,50$ and 1,000 where $\alpha=.05$ are $1.52,0.87,0.68$ and 0.15 , respectively. The critical values for kurtosis where $n=10,30,50$ and 1,000 where $\alpha=.05$ are 3.04 , $1.75,1.36$ and 0.30 , respectively. 
Table 3. Comparison of variances for trading, business days, trading-restricted, business days and trading, non-business days

\begin{tabular}{llrrrrr}
\hline \multicolumn{1}{c}{ Day } & Statistic & Market & Small-cap & Large-cap & $\begin{array}{c}\text { Market } \\
1958-87\end{array}$ & $\begin{array}{c}\text { Market } \\
1987-2007\end{array}$ \\
\hline All other days & Variance & 0.714 & 0.505 & 0.672 & 0.594 & 0.893 \\
Labour Day (VIC) & Variance & 0.719 & 0.824 & 1.535 & 0.446 & 1.103 \\
& $p$-value & 0.901 & 0.807 & 0.184 & 0.224 & 0.679 \\
Easter Thursday & Variance & $\mathbf{0 . 2 5 3}$ & 0.392 & 0.561 & $\mathbf{0 . 1 1 9}$ & 0.411 \\
& $p$-value & 0.044 & 0.898 & 0.611 & 0.018 & 0.374 \\
Bank Holiday & Variance & $\mathbf{1 . 2 6 0}$ & 0.846 & 0.709 & $\mathbf{0 . 1 5 2}$ & 0.961 \\
& $p$-value & 0.042 & 0.173 & 0.766 & 0.042 & 0.375 \\
Labour Day & Variance & 0.599 & 0.315 & 0.817 & 0.578 & 0.625 \\
(NSW) & $p$-value & 0.662 & 0.713 & 0.751 & 0.691 & 0.982 \\
Melbourne Cup & Variance & $\mathbf{0 . 3 0 4}$ & 0.401 & 0.552 & $\mathbf{0 . 1 9 2}$ & 0.439 \\
Day & $p$-value & 0.043 & 0.823 & 0.642 & 0.028 & 0.332 \\
Last day before & Variance & $\mathbf{0 . 1 5 4}$ & $\mathbf{0 . 0 6 8}$ & $\mathbf{0 . 1 1 9}$ & $\mathbf{0 . 1 1 2}$ & $\mathbf{0 . 2 2 3}$ \\
Christmas & $p$-value & 0.002 & 0.034 & 0.011 & 0.016 & 0.058 \\
Last day of the & Variance & 0.342 & 0.140 & 0.399 & $\mathbf{1 . 7 1 3}$ & 0.578 \\
year & $p$-value & 0.146 & 0.186 & 0.302 & 0.075 & 0.683 \\
\hline Notes: Market (All & Ordinaries) & $6 / 01 / 1958-13 / 08 / 2007$, Small-cap (Small Ordinaries) & $4 / 01 / 1994-$ \\
31/08/2007, Large-cap (ASX100) & $1 / 06 / 1992-31 / 08 / 2007$, Market 1958-1987 6/01/1958 - 19/10/1987, \\
Market 1987-2007 & - 20/10/1987 & $-13 / 08 / 2007$. & $p$-values are for Levene’s equality of variance tests, \\
return variances rounded to three decimal places. Significant differences in variance in bold. &
\end{tabular}

Table 4. Comparison of returns for trading, business days, trading-restricted, business days and trading, non-business days

\begin{tabular}{llrrrrr}
\hline \multicolumn{1}{c}{ Day } & Statistic & Market & Small-cap & Large-cap & $\begin{array}{c}\text { Market } \\
1958-87\end{array}$ & $\begin{array}{c}\text { Market } \\
1987-2007\end{array}$ \\
\hline All other days & Mean & 0.028 & 0.021 & 0.031 & 0.034 & 0.018 \\
Labour Day (VIC) & Mean & -0.047 & 0.049 & $\mathbf{0 . 2 6 3}$ & $\mathbf{- 0 . 1 9 8}$ & $\mathbf{0 . 1 8 1}$ \\
& $p$-value & 0.631 & 0.253 & 0.041 & 0.029 & 0.093 \\
Easter Thursday & Mean & 0.088 & -0.013 & -0.186 & $\mathbf{0 . 2 1 2}$ & -0.098 \\
& $p$-value & 0.317 & 0.405 & 0.379 & 0.043 & 0.496 \\
Bank Holiday & Mean & 0.016 & -0.259 & -0.150 & 0.594 & -0.215 \\
Labour Day & $p$-value & 0.909 & 0.361 & 0.411 & 0.269 & 0.409 \\
(NSW) & Mean & 0.058 & 0.150 & 0.063 & 0.219 & -0.010 \\
Melbourne Cup & $p$-value & 0.744 & 0.335 & 0.702 & 0.401 & 0.848 \\
Day & Mean & 0.179 & 0.221 & $\mathbf{0 . 4 4 6}$ & 0.069 & $\mathbf{0 . 3 3 9}$ \\
Last day before & $p$-value & 0.251 & 0.463 & 0.057 & 0.950 & 0.089 \\
Christmas & Mean & $\mathbf{0 . 3 6 0}$ & 0.279 & $\mathbf{0 . 3 4 6}$ & $\mathbf{0 . 3 5 1}$ & $\mathbf{0 . 3 7 6}$ \\
Last day of year & -value & 0.001 & 0.722 & 0.047 & 0.000 & 0.025 \\
& Mean & $\mathbf{0 . 2 9 8}$ & $\mathbf{0 . 4 4 8}$ & 0.137 & $\mathbf{0 . 2 5 9}$ & $\mathbf{0 . 3 4 2}$ \\
& $p$-value & 0.011 & 0.005 & 0.412 & 0.056 & 0.100 \\
\hline
\end{tabular}

Notes: Market (All Ordinaries) 6/01/1958 - 13/08/2007, Small-cap (Small Ordinaries) 4/01/1994 31/08/2007, Large-cap (ASX100) 1/06/1992 - 31/08/2007, Market 1958-1987 6/01/1958 - 19/10/1987, Market 1987-2007 - 20/10/1987 - 13/08/2007. $p$-values are for Wilcoxon non-parametric tests of mean differences, returns rounded to three decimal places and expressed as percentages. Significant differences in mean in bold. 
Table 5. Estimated regression equation for trading-restricted, business days and trading, non-business days

\begin{tabular}{|c|c|c|c|c|c|c|c|c|c|c|}
\hline & \multicolumn{2}{|c|}{ Market } & \multicolumn{2}{|c|}{ Small-cap } & \multicolumn{2}{|c|}{ Large-cap } & \multicolumn{2}{|c|}{ Market 1958-87 } & \multicolumn{2}{|c|}{ Market 1987-2007 } \\
\hline & Coefficient & Std. Error & Coefficient & Std. Error & Coefficient & Std. Error & Coefficient & Std. Error & Coefficient & Std. Error \\
\hline Constant & $0.028^{* * *}$ & 0.009 & 0.021 & 0.013 & $0.031^{* *}$ & 0.012 & $0.034^{* * *}$ & 0.012 & 0.018 & 0.014 \\
\hline Labour Day (VIC) & -0.047 & 0.088 & 0.049 & 0.234 & 0.263 & 0.309 & $-0.198^{*}$ & 0.120 & 0.181 & 0.229 \\
\hline Easter Thursday & 0.088 & 0.070 & -0.013 & 0.172 & -0.186 & 0.187 & $0.212^{* * *}$ & 0.062 & -0.098 & 0.140 \\
\hline Bank Holiday & 0.016 & 0.191 & -0.259 & 0.237 & -0.150 & 0.204 & 0.594 & 0.433 & -0.215 & 0.214 \\
\hline Labour Day (NSW) & 0.058 & 0.076 & 0.150 & 0.150 & 0.063 & 0.226 & 0.219 & 0.252 & -0.010 & 0.177 \\
\hline Melbourne Cup Day & $0.179^{*}$ & 0.096 & 0.221 & 0.169 & $0.446^{* *}$ & 0.186 & 0.069 & 0.080 & $0.339^{*}$ & 0.145 \\
\hline Last day before Christmas & $0.360^{* * *}$ & 0.031 & $0.279^{*}$ & 0.069 & $0.346^{* * *}$ & 0.086 & $0.351^{* * *}$ & 0.061 & $0.376^{* * *}$ & 0.103 \\
\hline Last day of the year & $0.298^{* * *}$ & 0.074 & $0.448^{* * *}$ & 0.100 & 0.137 & 0.158 & $0.259^{* * *}$ & 0.080 & $0.342^{* *}$ & 0.166 \\
\hline$R^{2}$ & 0.0011 & - & 0.0029 & - & 0.0024 & - & 0.0021 & - & 0.0019 & - \\
\hline Adjusted $R^{2}$ & 0.0006 & - & 0.0010 & - & 0.0007 & - & 0.0012 & - & 0.0005 & - \\
\hline F-statistic & 2.0030 & - & 1.4391 & - & 1.3340 & - & 2.2905 & - & 1.3742 & - \\
\hline$p$-value & 0.0473 & - & 0.1848 & - & 0.2297 & - & 0.0249 & - & 0.2115 & - \\
\hline
\end{tabular}

Notes: Market (All Ordinaries) 6/01/1958 - 13/08/2007, Small-cap (Small Ordinaries) 4/01/1994 - 31/08/2007, Large-cap (ASX100) 1/06/1992 - 31/08/2007, Market 1958-1987 6/01/1958 - 19/10/1987, Market 1987-2007 - 20/10/1987 - 13/08/2007. All standard errors include Newey-West corrections for serial correlation and/or heteroskedasticity. Asterisks indicate significance at the ${ }^{*}-.10,{ }^{* *}-.05$ and ${ }^{* * *}-0.01$ level. F-statistic and $p$-value is test of the null hypothesis that all slope coefficients are jointly zero. 